\title{
Veřejná antropologie ve 21. století, s některými př́íklady z Norska
}

\author{
Thomas Hylland Eriksen
}

DOI: 10.21104/CL.2016.1.02

\author{
Public Anthropology in the 21st Century, \\ with Some Examples from Norway
}

\begin{abstract}
Although there seems to be broad agreement within the discipline about the desirability of a public anthropology, there is less certainty, or agreement, not only about how to achieve it in a responsible way but also about its very raison-d'être. What should an anthropology which engages closely with non-academic publics seek to achieve? Starting with a historical overview, the article argues that the lack of a clear societal task or assignment liberates anthropology from problem solving for the state, enabling it to stimulate the collective imagination by making bold comparisons and unexpected conjectures. The empirical examples from Norway show how public anthropologists can successfully mix the 'light' and the 'heavy' in getting their argument across and raising anthropological issues while also engaging with a broad, non-academic public.
\end{abstract}

Keywords public anthropology, Norway, history of anthropology, interdisciplinarity.

Článek vychází z hlavní přednášky autora na sympoziu EASA „Making anthropology matter", Vila Lanna, Praha, 14.-15. ř́ina 2015, s podporou Akademie věd České republiky a České asociace pro sociální antropologii.

Contact Prof. Thomas Hylland Eriksen, University of Oslo, Department of Social Anthropology, Norway; e-mail: t.h.eriksen@ sai.uio.no; http://hyllanderiksen.net.

Jak citovat / How to cite Eriksen, Thomas Hylland. (2016). Veřejná antropologie ve 21. století, s některými prríklady z Norska. Český lid 103, 37-50. doi:http:// dx.doi.org/10.21104/CL.2016.1.02 
Vztah antropologie $k$ širšímu veřejnému prostoru prošel několika fázemi, nebo jinak řečeno př́livy a odlivy. Do konce 19. století antropologie jako samostatná intelektuální disciplína téměř neexistovala, jednalo se spíše o vytříbenou zálibu či nezáměrný, avšak nikoli nevítaný vedlejší efekt dobývání a kolonizace. Mezi odborníky, kteří přispěli k utváření antropologie jako samostatného vědního oboru, patřili například Lewis Henry Morgan ve Spojených státech nebo Henry Maine a Edward Burnett Tylor ve Velké Británii. Ti všichni se zařadili do širšího myšlenkového systému a vědeckého bádání. Ke skutečné profesionalizaci antropologie jako akademického oboru došlo na přelomu 20. století, což pozdějším antropologům postupně umožnilo odklonit se od společenských problémů a dalších způsobů zkoumání lidské kultury a společnosti. Přestože mnoho antropologů 19. století nelze považovat za „veřejné antropology“ $v$ dnešním slova smyslu, s veřejností byli v intenzivnějším kontaktu než většina akademických antropologů 20. století.

Rostoucí institucionalizace antropologie jako akademického oboru umožnila ve 20. století mnoha antropologům, aby se ze společnosti stáhli do ústraní (Eriksen 2006; Low - Merry 2008). Snahy některých z nich, jako byl například Alfred Reginald Radcliffe-Brown, aby se z antropologie stala „skutečná věda“ po vzoru fyziky a biologie, tento únik do věže ze slonoviny podporovaly, a jelikož po druhé světové válce počet odborníků zabývajících se antropologií prudce stoupl, rozrostlo se i profesní společenství natolik, že mohlo začít žít ve vlastním světě. Stejně jako třeba rozvíjející se firma začalo být toto společenství zahleděné do sebe, samoreprodukční a soběstačné, dokud se v důsledku strmého demografického růstu o několik desetiletí později nezačaly bořit dané hranice a nezačalo přibývat přeběhlíků.

Posun od otevřenosti k uzavřenosti však nebyl nikterak jednoznačný. Významní antropologové, kteří přispěli k institucionalizaci této disciplíny, především Franz Boas, se ve skutečnosti o širší společenské problémy zajímali; sám Boas byl významným veřejným kritikem rasové pseudovědy. Mezi jeho studenty patřila např́íklad Margaret Meadová, kterou jistě není třeba dlouze představovat: jako autorka čtyřiačtyřiceti knih a více než tisíce článků, která s neutuchající energií pracovala až do své smrti v roce 1978, byla tedy i ve 20. století nepochybně veřejnou antropoložkou par excellence. Byli i mnozí další, jejichž práce byly předmětem zájmu i mimo akademickou sféru a kteří se různým způsobem zapojili do celosvětového dění. Bronislaw Malinowski pořádal přednášky o primitivní ekonomice pro všechny, kteří byli ochotni naslouchat, Marcel Mauss se angažoval na francouzské politické scéně jako umírněný socialista a daly by se najít i další příklady.

V určitém smyslu zůstali antropologové vždy v kontaktu s veřejností mimo antropologickou akademickou sféru. Někdy to vedlo k jejich akademické marginalizaci - snadno mohli být odepsáni pro svou intelektuální lehkovážnost, pokud se věnovali hájení zájmů určité skupiny nebo jiné praktické činnosti, například pro rozvojové agentury. Mnozí si také všimli (např. Pels - Salemink 
1999; Borofsky 2011), že v antropologii existuje zřejmá, i když nejspíše nepříliš produktivní tendence povyšovat čistý výzkum nad výzkum aplikovaný. Stejně tak je sporné ono pojetí hierarchie, kdy čistě akademické práce pro úzký okruh znalců stojí nad srozumitelným psaním pro širokou veřejnost. Ve skutečnosti většina antropologů, jejichž práce čte mnoho studentů, věnuje převážnou část své intelektuální energie základnímu výzkumu a teorii, a je tedy třeba mít na paměti, že spolu s nimi vždy existovali i další antropologové, kteří se bud' usilovně snažili vyvolat širší diskusi o stavu lidstva, nebo se aktivně snažili zmírňovat lidské utrpení a přispívat ke společenským změnám.

V našem světě četných nadnárodních sítí a globálních toků se rozlišení ostatně od počátku diskutabilní - mezi „námi, kteří poznáváme“, a „jimi, kteří jsou předmětem studia“, stalo zcela neudržitelným a antropologové se nyní pouštějí do terénu a vytyčují si témata výzkumu způsobem, který byl ještě v minulé generaci nemyslitelný (viz např. MacClancy 2002). Jak uvádějí Sam Beck a Carl Maida (2013), současný svět je v mnoha ohledech bez hranic. Destabilizace hranic přinesla $\mathrm{z}$ hlediska antropologického výzkumu mnohé důsledky, přičemž některé z nejvýznamnějších dopadů se stále více projevují v diskusích o veřejné antropologii: Kdo může o čem legitimně promlouvat a za koho může hovořit? Jaká jsou hodnoticí kritéria dobré etnografie? Co mohou antropologové nabídnout společnostem, jež studují? A - v nejširším slova smyslu - jaký je přesný vztah mezi antropologickým výzkumem a studiem sociálních a kulturních světů? Tyto otázky, které byly relevantní vždy, se nyní staly nevyhnutelnými a v našem 21 . století - ve světě bez hranic - se na ně odpověd' hledá stále obtížněji.

Antropologie byla v minulosti velmi úspěšná v boji proti rasovým předsudkům a biologickému determinismu, což vyústilo - s přispěním např́íklad Margaret Meadové - v kulturní změny a vedlo k předkládání nečekaných analogií a provokujících kontrastů, třeba v úspěšné „přetvoření exotického ve známé a známého v exotické“. V posledních desetiletích jsme však nebyli schopni si určit jednotný veřejný program - slovo veřejný zde záměrně používám velmi široce, aby zahrnovalo postoje médií, politiků, studentů i všeobecnou intelektuální diskusi -, a to je poměrně závažný problém. Neznamená to, že se antropologové většinou zabývají neužitečnými nebo nerelevantními otázkami, že jsou ponořeni do výlučné, vysoce sofistikované činnosti, které rozumějí pouze oni sami a která se podobá „hře se skleněnými perlami“, jak ji popsal Herman Hesse ve svém posledním a nejdůležitějším románu Das Glasperlenspiel, ${ }^{1}$ do angličtiny přeloženém pod názvem The Glass Bead Game nebo Magister Ludi (Hesse 1949 [1943]). Hra se skleněnými perlami nemá jiný cíl než umožnit hráčům ukázat oslňující dovednosti a virtuozitu ducha, a jak zjistí protagonista románu Joseph Knecht, kvůli výhradnímu soustředění na

1 Hra se skleněnými perlami. Román vyšel česky poprvé v roce 1996 v nakladatelství Volvox Globator. Pozn. redakce. 
hru, které se od nich vyžaduje, ztrácejí hráči schopnost žít ve skutečném světě. Hessův román se zabývá problémem uzavřeného akademického úsilí vyvíjeného jen pro uspokojení sebe sama, které mimo akademický svět pozbývá na významu. O spisovatelích a básnících je známo, že právě takto nahlíželi na studium literatury, především v jeho poststrukturalistických verzích. Ale antropologie? Ta samozřejmě ne. To, co mnohé $\mathrm{z}$ nás $\mathrm{k}$ antropologii přivedlo především - možnost pokládat základní filozofické otázky a zároveň být ve styku se skutečnými lidmi a jejich realitou -, tu stále existuje. Avšak k lítosti nás všech antropologie velkou měrou i nadále žije ve svém vlastním světě.

\section{Antropologie jako kulturní kritika}

Zdálo by se, že v rámci oboru panuje široká shoda ohledně potřebnosti veřejné antropologie. Menší jednota již panuje v názoru na způsob, jak jejího využití odpovědně dosáhnout, jaký je vlastně skutečný raison-d'être tohoto oboru. K jakým výsledkům by měla antropologie, která navazuje úzký vztah s neakademickou veřejností, posléze dospět? K otázce lze přistoupit více způsoby.

Stanovisko vyslovené v době radikálních studentských hnutí v 60. letech 20. století považovalo antropologii za odvětví nedílně spjaté s kritikou ve vágně levicovém slova smyslu (např. Berreman 1968). Jelikož antropologové jsou blíže „obyčejným lidem“ než jiní vědečtí pracovníci - včetně sociologů - vede práce v terénu k získání zkušeností a vytvoření společenských vazeb, z nichž může logicky vyplývat angažovanost antropologů při obhajování místních komunit čelících potenciálnímu konfliktu s korporacemi nebo státy. Nepochybně je pravda, že antropologové, jednající nebo píšící v zájmu lidí, které zkoumají, stávají se tím často obhájci něčeho jedinečného a místního oproti různým formám standardizace, státní moci a globálního neoliberalismu. Jakkoli je to často chvályhodný a někdy i nutný úkol, kritická role veřejné antropologie může jít i dál, než je obhajoba různých druhů místních hnutí. To je patrné především - nikoli však výlučně - když se antropologové zapojí do řešení problémů ve vlastní společnosti.

Provádění antropologického výzkumu v domácím prostředí má své výhody i nevýhody, které většinou plynou z úzkého vztahu výzkumníka a zkoumaných. O tomto jevu spíše teoretizují sociologové než antropologové, z nichž někteří stále ještě uvažují o „domácí antropologii“ jako o výjimce. $V$ době, kdy poststrukturalismus začal nahrazovat neomarxismus jakožto dominantní neortodoxní teoretickou orientaci v sociálních vědách, Giddens (1984) vyzdvihl, že sociolog vstupuje se svou společností do „dvojitě hermeneutického“ vztahu, protože koncepce a analýzy sociálních věd jsou založeny na laických koncepcích a zároveň je ovlivňují. Jinými slovy dochází k obousměrnému hermeneutickému procesu. Antropologické pojetí etnicity se například stalo součástí běžného diskurzu, zatímco politické pojetí integrace (týkající se menšin) ovlivnilo sociální výzkum v této otázce. 
Několik let před Giddensem popsal podobnou dualitu ve své stěžejní práci filozof Hans Skjervheim (1957) a zahájil tak norskou kritiku pozitivismu. Ukázal, že sociolog není vzdálený, objektivní pozorovatel, ale účastník a pozorovatel zároveň (epistemologické postavení, které nelze zaměňovat s metodou zúčastněného pozorování), a že proto neexistuje neutrální pozice, z níž by se mohlo na společnost nahlížet.

Jinými slovy, sociologové jsou spjati s širším veřejným diskurzem a společenskými problémy, at už se jim to líbí, nebo ne; kritici pozitivismu dokonce již dlouho poukazují na to, že to platí pro všechna vědecká zkoumání. Jürgen Habermas, který psal své studie v době radikálního studentského hnutí na konci 60. let 20. století, rozlišoval mezi třemi poznávacími zájmy (Erkenntnisinteressen, Habermas 1971/1968), jež spojoval s třemi hlavními oblastmi akademického zkoumání. Vývoj přírodních věd je podle něj vyvolán odborným zájmem a svou podstatu našly ve výkladu vztahů a procesů v přírodě způsoby, které umožňují kontrolu a technologický pokrok. Vlastní poznávací zájem humanitních věd (Geisteswissenschaften) je oproti tomu praktický (v Kantově pojetí) a jeho cílem je prohlubovat a udržovat komunikativní společenství, na kterém závisí jak společnost, tak jednotlivci. A konečně poznávací zájem sociálních věd je osvobozující, cílem je odhalovat a odůvodňovat sílu vztahů ve společnosti a tím přispívat ke kritickému sebeporozumění jejích příslušníků. Habermas se obával, že odborný poznávací zájem začíná v akademických oborech příliš dominovat. Dnes můžeme snadno nalézt důkazy, které tento názor potvrzují, protože sociální výzkum převážně zadávají přímo nebo nepř́imo státní instituce, humanitní vědy jsou posuzovány na základě své užitečnosti a akademické úspěchy se posuzují podle měřítek nového konceptu řízení veřejných služeb „new public management“.2

\section{Irelevantní relevantním způsobem}

Díváme-li se na věc pohledem Habermase, Giddense, kritiky pozitivismu a vnímání potřeby veřejného závazku, je docela zřejmé, že ne všechny sociální vědy naplňují kritéria osvobozujícího poznávacího zájmu. Některé sociální vědy nebo možná jejich většina - jsou úzce spjaty se sociálním inženýrstvím, plánováním a formální strukturou společnosti a ve státním rozpočtu se sociální výzkum obhajuje odkazováním na jeho užitečnost. To patří do oblasti odborného poznávacího zájmu. Dialektická negace, široká škála postojů a přesvědčení spadajících pod hlavičku kritické sociální vědy, má za cíl bud' zlepšit vadný sociálně-hospodářský systém tím, že bude řešit rasismus, nerovnost, misogy-

2 Ve všech severských zemích proběhly bouřlivé diskuse také o narůstající byrokracii a o stále více se prosazujícím novém konceptu řízení veřejných služeb (New Public Management), který monitoruje a odměňuje produktivitu na vysokých školách např́klad na základě bibliometrických údajů nebo schopnosti financovat výzkum z externích zdrojů. Pozn. redakce. 
nii apod., nebo ho nahradit systémem lepším. Může to být osvobozující, ale ve skutečnosti to koncepčně závisí právě na tom, od čeho se chceme osvobodit.

Antropologie je v privilegovaném postavení, nebot má možnost vyvinout vedle udržování nebo sociální kritiky systému třetí způsob: takový, který je pravděpodobně více v souladu s pojetím osvobozujících znalostí, jaké v mládí zastával Habermas (a jeho radikálnější předchůdci ve frankfurtské škole). Jelikož jsem ve své podstatě rozvratným a nepředvídatelným partnerem v dlouhé konverzaci o tom, kdo jsme a kam jdeme, rád bych navrhl, že ve stále početnější rodině společenských a humanitních věd antropologie může a měla by na sebe převzít úlohu šibala Anansiho. V lidovém folkloru západní Afriky a Karibiku Anansi v podobě pavouka vždycky vyzraje na větší a silnější protivníky, protože svou zřejmou slabost umí vynalézavým a odvážným způsobem proměnit ve ctnost. Nikdo se ho nebojí, a tak dokáže všechny zaskočit a nosorožec, lev i krajta se stanou obět'mi své marnivosti.

Stejně tak typický antropologický přístup nepřináší osvědčené pravdy, nechce se zaplést s polarizujícími diskurzy a trvá na právu pohlížet na společnost současně jako „pozorovatel i účastník“. Nyní se dostáváme k zamyšlení nad situací v Norsku, kde je veřejných antropologů velmi mnoho (Eriksen 2006; 2013). V této malé zemi na severu Evropy antropologové často hovoří na veřejnosti na různých fórech, jako jsou Rotary kluby nebo třeba oblíbený literární dům v Oslu, komentují veřejné dění v médiích a někteří píší pravidelné sloupky, polemické články do novin a příležitostně též popularizační publikace.

V souladu s převažujícím instrumentálním pohledem na znalosti hovoří zástupci různých akademických oborů v Norsku někdy o svém „společenském poslání“ (samfunnsoppdrag). Co se týče společenských věd, ekonomové řídí zemi (prostřednictvím mocných institucí jako ministerstvo financí, Norský statistický úřad a Norská centrální banka), politologové se pídí po podstatě vlády na všech úrovních, od zahraniční politiky až po místní úřady, a sociologové obhajují sociální stát a genderovou rovnost. A jaká je úloha sociálních antropologů? V Norsku jich je mnoho, je tu pravděpodobně největší podíl antropologů na světě. Jelikož nemají žádné přesně definované oblasti, pracují v mnoha oborech, od rozvojových nevládních organizací a místní samosprávy až po komunikační agentury, knihovny a média, a navíc jsou také široce zastoupeni v akademické sféře, nejen na univerzitách a ve výzkumných ústavech různých typů. Bývalý předseda Sámského parlamentu byl vystudovaný antropolog, stejně jako bývalý ministr rozvoje. Přesto však antropologie zatím zůstává spíše posláním než profesí. Není jasné, z jakého důvodu právě tato země - nebo jakákoli jiná země - antropology potřebuje, a neustále probíhá boj za to, aby se prokázalo, proč je antropologie důležitá. Za tímto účelem se norští antropologové po mnoho let snaží ve veřejné sféře se zviditelnit. Navíc předmět nazvaný „sociologie a sociální antropologie“ je na středních školách nejoblíbenějším volitelným předmětem a řada Norů přinejmenším 
tuší, co antropologie znamená a co antropologové dělají. Panuje obecné přesvědčení, že antropologové jsou politicky vyhrocení, očekává se, že budou bránit imigranty a domorodé národy a kritizovat new public management a predátorský kapitalismus, budou se distancovat od norského nacionalismu či na něj v některých případech ironicky nahlížet a že budou upřednostňovat zelené a levicové strany. Jde sice o empiricky velmi zjednodušený pohled například nejznámější norský antropolog Fredrik Barth (narozen 1928) je většinou apolitický -, avšak vůbec ne mylný. Ekonomická antropologie se od ekonomických věd velmi liší: zabývá se nejen trhy, ale také výměnou darů, a nezajímá ji jen ziskovost, ale i lidská ekonomie. Když ekonomičtí antropologové studují centrální banky nebo finanční krizi (Holmes 2013; Appadurai 2015), pohlížejí na ně jako na kulturní systémy. Podobně i politická antropologie se dlouhodobě zaobírá symboly, příbuzenskou spřízněností a rituály, zatímco politické roztržky ji často zajímají jen okrajově.

V očích veřejnosti představují antropologové určitý typ intelektuálů, kteří upřednostňují rovnostářské, malé společnosti a kulturní rozmanitost. Avšak oproti jiným společenským vědám nemají antropologové své jasné společenské poslání - samfunnsoppdrag. Vypadá to, že jejich hlavním úkolem ve veřejné sféře je provádět neočekávaná srovnání, pokládat neobvyklé otázky a zpochybňovat zažité pravdy. Dělat si starosti mezi naše povinnosti nepatří. Ve výsledku tedy norští antropologové často sehrávali roli šibalů, podobně jako mazaný Popeláček (Askeladden) v norských pohádkách (Witoszek 1998) nebo Anansi v tradici západní Afriky a Karibiku (Eriksen 2013).

Avšak právě proto, že společnost nesvěřila antropologii soubor společenských otázek, kterými se má zabývat, nějakou oblast odpovědnosti nebo mandát vyřešit určitý problém, existuje skutečné riziko, že se antropologové z veřejného života stáhnou do ústraní. Stejně jako v jiných zemích se i norští antropologové raději baví mezi sebou a často ke svým debatám zapomínají přizvat i okolní svět. Autor vědecko-fantastických knih Tor Åge Bringsværd jednou připodobnil vztah společnosti a vědy k vyslání raketoplánu do vesmíru. Společnost do tohoto podniku vloží peníze a úsilí s tím, že raketoplán má za úkol přiletět zpět se zjištěnými poznatky. Bringsværd říká, že raketoplán příliš často ve vesmíru zůstane a nevrátí se, což je pro širší veřejnost zdrojem velkého zklamání.

S takovým pocitem je snadné se ztotožnit. K čemu by sloužilo využívání znalostí, kdyby obíhaly jen mezi zasvěcenými? To neznamená, že by každý antropolog měl poznatky svého oboru popularizovat, zapojovat se do stále nevděčnější mravenčí práce, již veřejná debata představuje, a chodit kázat o antropologii neznabohům. Ve skutečnosti by se antropologové, kteří se věnují styku s veřejností, neobešli bez těch, kdo se věnují složitému základnímu výzkumu jen pro zasvěcené, jenž nikdy neopustí prostory seminářů nebo internetové univerzitní knihovny. Jinak by veřejní antropologové neměli nic, s čím by mohli na veřejnost přijít. Někteří z nejoblíbenějších a nejvíce 
obdivovaných norských antropologů se většinou mimo akademickou půdu na veřejnosti neobjevovali. Příkladem může být zesnulý Reidar Grønhaug (1938-2005, viz Vike 2010). Intelektuálně zdatný, originální, nezištný a pro věc zapálený Grønhaug byl tak uzavřený a nesmělý, že téměř nepublikoval ani vlastní práce a nechával nedokončené texty ležet $v$ šuplíku, avšak alespoň ty nejlepší z nich v nacyklostylované podobě kolovaly mezi studenty a kolegy. Dobrým příkladem je neuvěřitelně originální text Transaction and signification (Grønhaug 1975), oduševnělá syntéza Bartha a Lévi-Strausse, kde je ústředním motivem opětovná analýza scény v hospodě z díla Clyda Mitchella The Kalela Dance (Mitchell 1956). Mohli bychom zmínit i mnohé další.

Napětí mezi vnitřním a vnějším, mezi otevřeností a uzavřeností, hromaděním a sdílením znalostí představuje základní dilema v dynamice všech skupin. Jednu verzi tohoto napětí skvěle popsal Sahlins ve svém starém, nezapomenutelném, i když diskutabilním článku Poor man, rich man, big man, chief (Sahlins 1963), ${ }^{3}$ v němž popisuje strukturální dilema melanéského náčelníka. Aby si upevnil mocenskou základnu, musí trávit nezanedbatelné množství času se svými příbuznými a př́znivci ve vesnici a nabízet jim dary. Musí však zároveň navazovat spojenectví s cizími lidmi, aby předcházel válce a sporům, ale také aby rozšiřoval sféru svého vlivu. Pokud však náčelník investuje do vnějšího světa času a prostředků příliš mnoho, jeho příbuzní a příznivci začnou reptat a mohou ho dokonce sesadit. Musí tedy neustále balancovat na tenké hraně mezi vnitřní soudržností skupiny a vytvářením spojenectví, neboli mezi konsolidací a expanzí.

Antropologům, kteří se na své cestě vychýlili, aby mohli komunikovat s neantropologickou veřejností, byly často připomínány širší souvislosti Sahlinsova pohledu. Pokud vyjdete vstříc vnějšímu světu, můžete vzkvétat, obohatit vlastní lidi, učinit je slavnějšími a přitažlivějšími pro ostatní, ale zároveň to může být váš konec, protože začnete obchodovat s cizáky, aniž byste spláceli své dluhy doma.

Norští antropologové se už před časem rozhodli to risknout. Norskou antropologii odlišuje především hojná př́itomnost antropologů v této zemi a také jejich časté vystupování na veřejnosti, at' už jednotlivě, nebo kolektivně. Norští antropologové přesně jako hodinky každý rok před Vánocemi vysvětlují v rádiu a v novinách pozadí toho, proč si dáváme dárky, a často přitom odbočí až k potlachům či k Melanésii; na jaře se vyjadřují k rituálům a symbolům fotbalových fanoušků; kolem Velikonoc píší nebo hovoří o zvláštním norském zvyku trávit Velikonoce lyžováním na horách; a na podzim se účastní vážných diskusí o významu muslimského šátku v rostoucí muslimské menšině v Norsku. Riskují, že se stanou dvorními šašky akademické sféry, ale zrovna

3 To je mimochodem také název písně, kterou od počátku 90. let 20. století hraje skupina studentů a mladých zaměstnanců na oslavách. Text napsal Bjarne Træen a skupina pod názvem Pigs for the Ancestors vystupovala v nejrozmanitějším složení. Při řadě př́ležitostí jsem tuto skupinu trochu doprovázel na saxofon. 
tak se mohou stát i těmi, kteří budou schopni mocným říkat pravdu, protože nemají žádné postranní zájmy. Abychom použili Kunderova protikladu z knihy The Unbearable Lightness of Being 4 (1984), v práci veřejného antropologa najdeme lehkost i tíhu. Nyní se prostřednictvím několika příkladů zamyslím nad vztahem lehkosti a tíhy v norské veřejné antropologii a ukážu, že se situace na přelomu tisíciletí změnila.

\section{Lehkost a tíha ve veřejné antropologii}

Antropolog Runar Døving, který se zabývá zkoumáním jídla a jeho konzumace, psal ve své dizertační práci o změnách a kontinuitě stravovacích návyků v jisté vesničce na jihovýchodě Norska. Protože byl v době, kdy pracoval na své dizertaci, aktivní ve veřejné sféře, napsal do osloských novin Dagbladet polemický článek, v němž obhajoval párek v rohlíku před těmi, kteří jej zatracovali. Aniž by jedinkrát zmínil jméno Bourdieu, útočil Døving (2002) přesvědčivě a neúnavně na snobství v jídle a na nové kulinářské zvláštnosti, vyplývající z různých forem individualismu a snahy o odlišení, které spojoval s neoliberální deregulací. článek byl napsán energicky a zaujatě, je lehkovážný a zábavný, avšak zároveň vážný a tíživý. Døving sleduje vývoj zpracovávání potravin od předmoderní do průmyslové doby a zdůrazňuje, že hromadně zpracovávané potraviny, jak je známe dnes a jimž se kulinářské elity vysmívají, jsou chutnější a zdravější než jedinečné, pečlivě ručně připravované jídlo, o kterém mají snobové romantické představy. Ǩíká, že současný dostatek průmyslově zpracovaných potravin by se ve skutečnosti měl oslavovat, když vezmeme v úvahu, jak malé produkce se při velmi tvrdé práci dosahovalo ještě před několika generacemi. Dále popisuje, že k výrobě potravin musely přispívat děti, že ona drahocenná a luxusní potravina jménem máslo byla distribuována v otevřených, nehygienických obalech (a rychle se tudíž kazila) a že otec rodiny musel pracovat padesát hodin týdně, zatímco matka a nejstarší děti trávily odpoledne tím, že opíraly a nasolovaly slanečky. Z Døvingovy na první pohled lehkovážné obrany párku v rohlíku „s tou skvělou rajčatovou omáčkou - kečupem“ se stala kritika nových třídních rozdílů a obrana výdobytků moderní výroby potravin. Tento článek je jednou z jeho nejlepších polemik, rozšiřuje nevelký počet př́spěvků k nedávno vzniklé antropologické diskusi o jídle, i když se tváří jako obrana párků v rohlíku, rybího nákypu (fish pudding) a konzervovaných makrel.

O několik let dřive provedl antropolog Hans Christian (Tian) Sørhaug aplikovaný výzkum drogově závislých v Oslu. Došel například k tomu, že je lze právem srovnávat s lovci a sběrači: jejich skladovací kapacita je velmi nízká, spoléhají se na okamžitou návratnost investice, kočují, velikost skupiny je

$4 \quad$ Nesnesitelná lehkost bytí. Román vyšel česky poprvé v roce 1985 v Sixty-Eight Publishers v Torontu, v Česku pak v roce 2006 v Brně v nakladatelství Atlantis. Pozn. redakce. 
proměnlivá, ale stále relativně malá a existuje trvalé, přijímané napětí mezi egoismem a solidaritou. Řídí se tzv. ekonomikou sklízení (harvesting economy). Byl to skutečný, originální objev a přispěl k pochopení tíživé situace městských lidí závislých na heroinu. Takové srovnání by však mohlo být snadno považováno za lehkovážné, až nepatřičné. Společnost, v níž lidé závislí na drogách žijí, a mechanismy, kvůli kterým se do takové situace dostali, se koneckonců od světa lovců a sběračů výrazně liší, a abyste byli schopni takové srovnání docenit, musíte se oprostit od svých dosavadních představ o kulturních rozdílech. A musíte být schopni „přepínat“ mezi hravým režimem zkoumajícím různé možnosti a živé světy a vážnými starostmi o tíživou situaci lidí bez domova závislých na heroinu.

Podobně byl v osloských novinách Aftenposten někdy na konci 90. let 20. století zveřejněn rozhovor s Eduardem Archettim o dlouhých maturitních oslavách, kterým holdují norští adolescenti po ukončení studia. Tuto jedinečnou tradici, oslavy známé pod názvem russefeiring (Eriksen 2013), doprovází alkohol a bujaré večírky v parcích a na jiných veřejných místech trvají přes dva týdny, od 1. do 17. května (norský Den ústavy), kdy určitým způsobem vrcholí. Když byl Archetti, sám v té době otec dvou dospívajících dětí, dotázán na tento rituál, odpověděl, že pro mladé lidi je to silný a smysluplný zážitek, byt jen proto, že pro mnohé je to poprvé, kdy se účastní rituálu zahrnujícího sex a omamné látky. Můžeme téměř jistě předpokládat, že tento komentář značnou část úzkostlivých rodičů přiliš neuklidnil. Důležité však je, že Archetti nepovažoval za své společenské poslání, aby sehrál úlohu starostlivého sociologa a jako takový apeloval na rodiče, že je důležité, aby zůstali vzhůru a s potomky si promluvili, až se vrátí z oslavy domů, nebo že by dívky neměly nikdy chodit opilé samy domů. Ze své pozice se na oslavy maturit díval jako na rituál, nikoli jako na společenský problém.

Krátce jsem představil tři antropologické intervence ve veřejném prostoru, které - oproti většinové veřejné antropologii - představují komplexní rétorické stanovisko, kde zamýšlený logos podstupuje riziko, že bude přehlušen vnímaným pathosem. Přestože mají všechny vážný záměr, obsahují zároveň lehký, hravý rozměr, někdy dokonce i patrné zesměšnění. Všichni zmínění antropologové jimi zariskovali, což je ale mezi sociálními antropology jistě běžnější než v ostatních akademických profesích v Norsku. Riziko znamená, že nebudete bráni vážně, protože lidé si zapamatují pouze vtípky a ne jejich kontext. To je známý problém politické satiry (pokud je příliš směšná, lidé zapomenou na to, že je míněna vážně) a science fiction (povrchní čtenáři si zapamatují technologii, ale nikoli filozofická nebo politická zamyšlení). Podobně i antropologové, kteří veřejnosti poodhalí svou srovnávací představivost, riskují, že budou odepsáni jako neodpovědní diletanti. Zůstává však otázkou, zda tento trochu neurčitý aspekt veřejné antropologie je vlastně nakonec problémem, nebo výhodou. 


\section{Anarchisté západní inteligence}

Od přelomu tisíciletí se doba změnila. V poslední době se norští antropologové, kteří jsou tak trochu anarchisty akademického světa, občas nečekaně stali součástí zábavního průmyslu. Řada z nás byla opakovaně nařčena z toho, že jsme se stali „zpěváky a tanečníky“. I když duch doby se v tomto století změnil a je zde méně prostoru pro neodpovědné hrátky s myšlenkami v porovnání se zlatou dobou postmoderního optimismu v 90. letech 20. století, můžete se u antropologů stále spolehnout na to, že když se jim poštěstí, mohou si dovolit ř́kat divné nebo neočekávané věci. Ovšem dnes, v době rostoucí islamofobie (v Norsku v současnosti dokonce přímo ve vládě), složitých problémů s uprchlíky, bující marketizace a instrumentálního pohledu na znalosti, ohrožujícího ruku v ruce s koncepcí new public management svobodu univerzit, se lehkost minulých let, ke které jsem uvedl několik př́ikladů, již téměř vytratila. Jakkoli za lehkostí, o níž jsem hovořil, vždy stály vážné obavy - Døvinga znepokojovaly třídní rozdíly, Archetti se zabýval bolestným i vzrušujícím přechodem k dospělosti, Sørhaug bezvýchodnou situací a iluzemi absolutní svobody u drogově závislých - bylo hrát úlohu pavouka Anansiho v zásadě neškodné a legitimní.

Připomínka toho, že lehkost se někdy může stát nesnesitelnou, mě poměrně strašným a osobním zpo̊sobem dostihla před několika lety. Ideologická polarizace již nějakou dobu pokračovala, posílena islámskými teroristickými útoky v New Yorku, Londýně a Madridu, a sociální antropologové byli stále více spojováni s naivním multikulturalismem, který se nezdařil. Po mnoho let někteří z nás zpochybňovali společenské hranice a pokládali kritické otázky zabývající se etnickým rozměrem norského nacionalismu. Poté, uprostřed léta 2011, vybuchla bomba. Většina, kterou antropologové tak pilně dekonstruovali, měla být nyní rekonstruována a mělo se za to, že $k$ těmto účelům je potřeba násilných prostředků.

Mimochodem, po teroristickém útoku v roce 2011, kdy nezaměstnaný pravicový extremista zabil 77 lidí, se „dekonstrukce většiny“ v Norsku stala omílanou frází. $V$ jeho prohlášení a videu na YouTube, které bezprostředně před útokem umístil na internet, mě na několika místech cituje - nejznámější citací (která se následně objevila na internetových stránkách extrémní pravice po celém světě) je můj názor vytržený z jednoho rozhovoru na stránkách osloské univerzity (www.uio.no/culcom), že je na čase, abychom dekonstruovali většinu, protože až dosud jsme věnovali př́liš mnoho pozornosti menšinám. Před teroristickým útokem a po něm bylo toto tvrzení (z roku 2009) často odsuzováno jako nenávistný projev proti norskému lidu a jeho původce byl označován za zrádce. Abych to shrnul, když jsem mluvil o dekonstrukci většiny, špatně jsem odhadl čtenáře. Koncept zpochybňoval hranici mezi námi a jimi a odkazoval k interní rozmanitosti etnických Norů jako možnému prostředku pro vytvoření abstraktní komunity, která by nebyla založena na rase a příbuzenství. Jelikož 
dekonstrukce znamená rozložení, etničtí nacionalisté měli pocit, že jejich hranice jsou ohroženy. Avšak i v optimistických 90. letech 20. století, kdy se norští antropologové vysmívali vážnému nacionalismu a šovinismu, za tím vždy stál vážný záměr. Pod rouškou lehkovážných vtipů jsme chtěli pokládat otázky o integraci a vyloučení v etnicky složitých společnostech, ptát se, zda etnický nacionalismus pomáhá při určování identity ve světě, který je „v pohybu“ (Bauman), a také se ptát, jaké může být smysluplné vymezení slova „my“. Chtěli jsme sdělit, sice poněkud normativně, ale na základě antropologických znalostí o kulturní rozmanitosti, že všechny lidské životy mají cenu, že solidarita s ostatními nemusí nutně sledovat etnickou linii, že zdánlivá společenství jsou méně homogenní, než se často předpokládalo, a že si lze bez problémů představit a vytvořit kolektivní identitu, která není založena na kulturní podobnosti. Po teroristickém útoku a jeho dohře, kdy se vyostřila ideologická polarizace kolem otázek identity a integrace v norské společnosti, se tato lehkost, typická pro antropologii posledních let, může stát jednou z prvních obětí.

A to je škoda, protože antropologie někdy dokáže pokládat ty nejtíživější otázky právě tehdy, když se tváří lehkovážně.

\section{Vyhýbání se zrádným nástrahám}

Protože řešení problémů pro účely vlád nebo korporací nepřipadá v úvahu, musejí si antropologové hledat jiné způsoby, jak být relevantní, nebo ještě jinak řečeno - jak to jednou v souladu s dualitou lehkost/tíha, jíž čelí veřejný antropolog, vyjádřil Tian Sørhaug -, ,,irelevantní jsme byli vždycky, avšak vypadá to, že v dnešní době si musíme pro svou irelevantnost najít nové způsoby“. Vnímání kulturní rozmanitosti se u převládající části společnosti posunulo agresivnějším, nemilosrdnějším a nepřátelštějším směrem a tento posun vyžaduje, aby veřejní antropologové změnili svou taktiku. Jelikož mezi norskou veřejností panuje o sociální antropologii určité povědomí, problém netkví v tom - jako tomu bylo v 60. a 70. letech 20. století -, že lidé nechápou, co antropologové říkají; rozumějí tomu velmi dobře, ale odmítají to jako irelevantní (zcestné) a potenciálně podvratné. A proto je stále složitější vést takové diskuse, které by byly produktivní, než tomu bylo před nedávným posunem směrem k silnějšímu potvrzování hranic a konzervativnějšímu pohledu na identitu.

Tyto otázky nelze v rámci krátkého příspěvku blíže vyřešit. Rád bych skončil připomenutím, že je především třeba vyvarovat se dvou nástrah, a to přílišného zjednodušování a zpátečnictví. To by měl být všeobjímající cíl veřejné antropologie - zjednodušit vše tak, jak je to jen možné, ale ne více (jak prý řekl Einstein); povzbuzovat představivost, ale nevyvolávat zmatení. Převažující poznávací režim v současnosti upřednostňuje nejen instrumentálně užitečné znalosti (užitečné tedy hlavně pro mocenské skupiny, především v politice a hospodářství), ale také cokoli, co se dá změřit (Eriksen 2015). Jelikož naše síla spočívá v tom, že přinášíme poznatky o jevech, které spočítat nebo 
změřit prostě nelze, musejí se antropologové snažit prokázat relevantnost svých irelevantních znalostí. Protože pokud nikdo nepochopí, co říkáme, není to známka hloubky naší myšlenky, ale chabých jazykových dovedností a zmateného myšlení. Jak jednou řekl Marshall McLuhan, „i bláto může vzbudit iluzi hloubky“.

Můžeme být zrnkem písku v soukolí, ale také můžeme otevírat nové perspektivy.

Únor 2016

\section{Literatura}

Appadurai, Arjun. 2015. Banking on Words: The Failure of Language in the Age of Derivative Finance. Chicago: University of Chicago Press.

Beck, Sam - Maida, Carl A. (eds.). 2013. Toward Engaged Anthropology. New York: Berghahn.

Berreman, Gerald. 1968. Is Anthropology Alive? Current Anthropology 9, 5: 391-396. Borofsky, Robert. 2011. Why a Public Anthropology? Kindle book, Center for Public Anthropology.

Døving, Runar. 2002. Kjendiskokker og ketchuphat ('Celebrity Chefs and Ketchup Hatred'). Dagbladet: 9 February.

Eriksen, Thomas Hylland. 2006. Engaging anthropology: The case for a public presence. Oxford: Berg.

Eriksen, Thomas Hylland. 2013. The Anansi position. Anthropology Today 29, 6: 14-17.

Eriksen, Thomas Hylland. 2015. What Everybody Should Know about NatureCulture: Anthropology in the Public Sphere and 'The Two Cultures'. In: Beck, Sam - Maida, Carl A. (eds.): Public anthropology in a borderless world. Oxford: Berghahn: Chapter 10.

Giddens, Anthony. 1984. The Constitution of Society. Cambridge: Polity.

Grønhaug, Reidar. 1975. Transaction and Signification. Typescript, University of Bergen.

Habermas, Jürgen. 1971/1968. Knowledge and Human Interests, tr. Jeremy Shapiro. Boston: Beacon Press.
Hesse, Hermann. 1949 [1943]. The Glass Bead Game. New York: Holt, Rinehart \& Winston.

Holmes, Douglas. 2013. Banking on Words: The Failure of Language in the Age of Derivative Finance. Chicago: University of Chicago Press.

Kundera, Milan. 1984. The Unbearable Lightness of Being. New York: Harper \& Row.

Low, Setha - Merry, Sally Engle. 2010. Engaged Anthropology: Diversity and Dilemmas. Current Anthropology 51, supp. 2: 203-226.

MacClancy, Jeremy (ed.). 2002. Exotic No More: Anthropology on the Front Lines. Chicago: University of Chicago Press.

Mitchell, J. Clyde. 1956. The Kalela Dance: Aspects of Social Relationships among Urban Africans in Northern Rhodesia. Livingstone: RhodesLivingstone Papers 27.

Pels, Peter - Salemink, Oscar (eds.). 1999. Colonial Subjects: Essays on the Practical History of Anthropology. Ann Arbor: University of Michigan Press.

Sahlins, Marshall. 1963. Poor Man, Rich Man, Big Man, Chief: Political Types in Melanesia and Polynesia. Comparative Studies in Society and History 5: 285-303.

Skjervheim, Hans. 1957. Deltakar og tilskodar ('Participant and Observer'). Mimeo. Oslo: Department of Sociology. Vike, Halvard. 2010. Reidar Grønhaugs metode - en kraftlinje i norsk sosialantropologi ('Reidar 
Grønhaug's Method - a Line of Power in Norwegian Social Anthropology'). Norsk antropologisk tidsskrift 21, 4: 211-222. Witoszek, Nina. 1998. Norske naturmytologier: fra Edda til økofilosofi (Norwegian Nature Mythologies: From the Eddas to Ecophilosophy). Oslo: Pax. 